\title{
South African Economic Development in SADC Sub-Regional Integration
}

\author{
Andrew O. Enaifoghe, Toyin C. Adetiba* \\ University of Zululand, KwaDlagenzwa, South Africa \\ andyransey@gmail.com, oluwatoyin9ja_333@outlook.com*
}

\begin{abstract}
Following the end of colonialism in the Southern African sub-region, the SADC has experienced a thorough rearrangement with South Africa as the front-runner as opposed to her pre-1994 stance on integration. African regional cooperation has nevertheless been revitalised in some ways as a result of the two major events which started in the beginning of the 1990s that include the abolition of the apartheid regime in South Africa, and the eventual stabilisation of both political and economic relationships in the Southern Africa sub-region. This study employs the use of content analyses to assess the position of South Africa investments in SADC. Through the use of regional integration, the study further examined various South Africa's Key Economy Performance since 1994 which are the main contributing factors to South African economic growth; furthermore, it looks at her material, commodity and political investment in the subregional integration process to determine if it serves as the strategy for National Economic Development for South Africa. The paper finds out that regardless of South Africa's economic clout within the SADC region, its Foreign Direct Investment is predominantly from its investment and market penetration of Southern Africa region while maintaining constant economic growth.
\end{abstract}

Keywords: Economic development, Integration, Regional cooperation, National development

\section{Introduction}

Broadly, African regional cooperation has been revitalised in some ways as a result of the two major events or developments which started in the beginning of the 1990s, this includes the abolition of the obnoxious apartheid regime in South Africa and eventual stabilisation of political and economic relationships in the Southern Africa sub-region. Overtly, this helped to strengthen the already existing regional integration in the Southern Africa States. Since the end of the Cold War (a state of geopolitical strain between the U S and the former Soviet Union after the Second World War over which of the two countries would hold economic and ideological influence over the world. The war lasted from 1947 - 1991. Ironically, there was no military engagement between the two states rather it was all a proxy war where the third -world countries were seen as "the pawn on the geopolitical chess board of the two superpowers")and with the rise of capable exchanging coalitions, there has been a renewed interest in South Africa regarding the need to create strong Regional Economic Integration (REI) mechanisms to promote economic growth for the region and by implication foster South Africa's National Development (SAND) trajectory.

The SADC appears to be among the best-integrated sub-regional organisation in Africa aided largely by South Africa's material, commodity and political investment in the region. However, a comparison study done by Fall, Vachon and Winckler (2014), showed that general economic execution of Regional Economic Cooperation (REC) does not efficiently convert into expanded intra-regional exchange. While transforming exports by sorts of goods, differences between levels of industrialization and improvement of RECs become more notable. SADC has all the earmarks of being less regionally incorporated and is more open to worldwide trade. Conversely, Economic Community of West African States (ECOWAS) and West African Economic and Monetary Union (WAEMU) are more coordinated territorially yet less integrated into global trade. But beyond a political procedure argued Fall, Vachon and WincklerDiery, (2014), intraregional exports appear to be in this way to be a moment best solution for SADC states. Therefore, the extent to which these investments aid South Africa's National development needs to be fully understood, hence, questioning the position of South Africa in the current SADC integration.

In terms of socio-political and economic stability, the Southern Africa is a highly fragmented sub-region in Africa; a political and economic situation that has made South Africa to see itself as the regional arbiter and why she has always support regional integration. Regional integration is said to be established when a group of countries come together and develop a formal agreement by way of treaties regarding how trade and economic activities will be conducted and exchange with each other. Hans (1978:12-21), defines integration 
as "the process whereby political actors in several distinct national settings are convinced to move their loyalties, desires and political exercises toward a new centre, whose institutions possess or demand jurisdiction over pre-existing national states". For Chingono and Nakana (2008:2), the final product of a procedure of political combination is another political group, superimposed over the pre-existing ones. Regional integration has showed itself verifiably in Africa, America and Europe as a bureaucratic push to encourage political unification and expansion of capitalism".

\section{Theoretical explanation}

At the centre of international relations is the nation-state and because nations have been affected by many transnational phenomena, there is need for state actors, political scientists as well as humanist to formulate the means to smoothen relationship among nations while helping to establish a long-lasting peace. The theory of regional integration was the brainchild of the functionalists. The functionalist approach according to Bolaños (2016:5) considers that nations maximize their [economic and political] interest owing to the assistance of international organizations based on functional rather than territorial principles. From the functionalists approach, this theory can be explained from two perspectives; political and economic which falls under the purview of this work. Bolaños (2016:10) however argues that regional integration can simply not exist if the involved countries are not physically interconnected.

Economic integration: Historically, economic integration among nations can be traced back to the period of World War II when the market economics of Western Europe were destroyed, hence the assertion that economic integration is a post-War phenomenon which came to official use following the Marshal Plan for the reconstruction of Europe after World War II. Debatably, the perception of integration after World War II as a tool within a regional development strategy has always been applied to developing regions with such approaches as integration by the market; complex integration, the functional approach, and the structural approach (Muneer et al., 2016). Economic integration, therefore includes different degrees or stages of integration preferential trade agreements, free trade areas (FTAs), customs unions (CUs), common markets (CMs), and economic and monetary unions (ECLAC, 2009) thus, making [economic and political] integration within the context of SADC either as a process or as a goal. To Balassa (1961), economic integration is both a process and a state of affairs. As a state of affairs, it is the absence of various forms of discrimination between national economies. As a process, it includes measures designed to abolish discrimination between economic units belonging to different nation states thus leading to formation of a political union (Bolaños, 2016; Etzioni, 1965).

Political integration: Political integration is the process whereby nations forgo the desire and ability to conduct foreign and key domestic policies independently of each other, instead; make joint decisions or delegate such process to new central organs; which implies greater depth, coordination, and harmonization of [economic and political] actions among members in the governmental and institutional spheres. In essence, new regional governance where political actors are severally persuaded to shift their political expectations based on the rule that guides the new regional organization emerged (Lindberg, 1963, ECLAC, 2009). One of the features of such integration is physical integration, featuring regional infrastructure projects as the key drivers of the organization. From the above, international political and economic integration can be understood as a characteristic aspect of regional integration through which groupings such as SADC are created between nations without the use of violence. Lindberg (1970) reinforced this assertion that nations group together because of feelings of good relations, confidence, and expectations that common economic and political problems will be resolved without recourse to conflict but engender a passionate concentrations of economic exchange of productive factors. Debatably, political integration occurs if there are linkages that elicit joint participation in decision making within the region. It therefore translates to mean that, as part of an inclusive process, regional integration to Lindberg (1970) can be explained as the development of a collective decision-making system among nations. Regional integration in relation to SADC for that reason can be treated as a means to improving regional economic development by removing trade inhibitions between SADC states while establishing certain elements of economic cooperation. To Schmitter (1970:836) regional integration is about how national units come to share part or all of-their decisional authority with an emerging international (sub-regional) organization 
South Africa and the Regional Economic Integration: Within Southern Africa, South Africa has the most firmly robust economy and by extension at continental level. Her regional and overall interests, however, lies at the heart of South Africa's remote approach in achieving the need to make deals that may inconvenience other SADC members. The financial and political quality of South Africa in the sub-region is unquestionable; perhaps the reason while South Africa is the present chair of the regional body and therefore its management position or role in the SADC as a sub-regional organisation is very important (SAnews, 2016). This also gave the right to South Africa to host the 37th Ordinary SADC Summit that took place in August 2017 as the chair of the organisation. This has earned the country an accolade of been described as the access-way to foreign direct investment to Africa. Institutional expansion has been progressively known to be essential to the integration course of the Southern African, the important character of these organisations in creating the correct system to regional integration has additionally been acknowledged.

The utmost vital systems aiding as regional integration schemes for Africa include the treaty creating the African Economic Community (AEC), and the Constitutive Act of the African Union (UNECA, 2009). The Abuja Treaty which creates the African Union affirmed that RECs shall be the structure of the African Union and RECs the foremost integrative fundamentals in Africa. However, the truth of RECs may likely keep researchers/academia curious about the place of the role played by organisations in regional integration. Coordination and harmonisation among RECs in Africa generally would therefore be seen as key to the socioeconomic development of the region. Practically, a well-coordinated and harmonised regional economic integration will probably guarantee that both internal and external powers impacting Africa's integration are measured and addressed. Besides, RECs will take a similar step or may be capable of gaining from each other without re-evaluating the wheel each time such harmonisation is realised.

The Abuja Treaty concentrates on the noteworthiness of building the African Economic Community (AEC) through harmonisation, coordination, and dynamic incorporation of the activities of RECs (SAHO, 2015). It is additionally rehashed in article 3 of the Constitutive Act of the AU that basically highlights the importance of arranging and fitting approaches among surviving RECs for the continuous acknowledgement of the Union (PVW/South Africa, 2016). Following the demise of apartheid, the SADC has experienced a thorough rearrangement with South Africa turning into its true front-runner as opposed to her essential aim. Amongst the fundamental goals of SADC are to accomplish advancement and monetary development, lighten neediness, improve the standard and personal satisfaction of the general population of Southern Africa and support the socially disadvantaged through territorial integration.

It also pursues other objectives such as propelling basic socio-political and economic quality frameworks and foundations, progressing and ensuring peace and security. It also works towards strengthening and joining the long-standing historical, social and cultural affinities and connections among the general population of the area. South Africa, being the key regional influence on board in the Southern Africa integration, has turned out to be fairly more viable in terms of its security and economic functions within the SADC. In 2007, the SADC member states built up a reserve negotiation power through which the association had achieved some level of success in intervening clashes in the Comoros and the Democratic Republic of Congo (Mutisi, 2016). Notwithstanding, over $66 \%$ of the SADC conventions on territorial integration have gone into drive and most substantive arrangements of the regional integration approach are on different levels of execution. As an integrating organisation, the SADC has recorded accomplishments on structure and restoration of transportation connection concerning its member states. In respect of exchange, the SADC aimed at accomplishing a Free Trade Area by the end of 2008 and furthermore start a SADC Customs Union by 2010 (Department of Economic Affairs, African Union, 2008), however the free trade area was only accomplished on August 2008 as expected, unfortunately after missing the 2010 deadline for the establishment of custom union, the SADC met in 2015 to negotiate a new target date for the transformation of the organisation into a Customs Union (CU), up until 2015 Ordinary Summit, SADC has yet to achieved the establishment of custom union in the sub-region by the end of 2016.

Notwithstanding its achievements, the SADC has its share of difficulties. For instance, with its blueprints to have a Free Trade Area (FTA) and a Customs Union in the year 2010, it therefore meant that it must have a framework for recollecting a definitive target to finish it on time, but for the socio-economic and political trauma facing some its member states reverse has been the case. It is essential to note also that within the 
SADC there is South African Custom Union (SACU), which is at a struggling condition of coordination as well as the Customs Union. There is a requirement to get all the SADC states to the level of Customs Union. However, the dual membership of some SADC states as members of the COMESA (Common Market for Eastern and Southern Africa) is making it difficult for SADC states to have its own particular Customs Union in 2008.

The World Trade Organization (WTO) rules which stipulate that nations cannot have a place with more than one Customs Union poses a serious challenge to nations (such as Tanzania) that are in cooperation with both the SADC and the COMESA. Jonathan (2004:1) saw that as for its objective of guaranteeing peace in the zone, the SADC has been moderately speculative about wielding its political muscle. The deteriorating political situation in Zimbabwe where the military has threatened to intervene in the ongoing political imbroglio is evidence (The Telegraph, November 13, 2017). Another challenge experienced in the Southern Africa region which has negative impact on the promotion of economic development with integration is the case of xenophobic assaults in South Africa. These attacks are perpetrated by black South Africans who spun against black non-nationals from different parts of Africa and the world and especially from other SADC states including Mozambique and Zimbabwe. Such attacks are contrary to the SADC's target of joining the longstanding historic, mutual and social similitudes and relations between the general populations of the subregion. The recent approach and strong commitment to the actualisation of the SADC's integration programmes by South Africa is highly commendable. The evolution of its relationships with its neighbours on the African continent is worth pondering (Omoro, 2008). South African remains an economic powerhouse in the Southern Africa and Africa at large. Relations between South Africa and other countries on the continent have been far from cordial for the most part of the past century. South Africa's transition from apartheid to democratic rule 23 years ago has had far-reaching implications for Sub-Saharan Africa as the fall of communism in the former Soviet Union had on the Eastern European bloc.

The Southern African Development Coordination Conference (SADCC) which was formed in 1980 under the arrangements of the Lusaka Declaration like the OAU's Lagos Plan of Action formed in 1980; to stimulate the establishment of local monetary groups as building alliances for an inevitable continental financial union(the Abuja Treaty of 1991),was formed generally, as a political and protective reaction by the Frontline States Angola, Botswana, Lesotho, Mozambique, Tanzania, Zambia, and Zimbabwe - to PW Botha's grandiose conception of the 'Constellation of Southern African States' (Jephias and Muyengwa, 2014) in the region. The SADCC wished to decrease economic dependency on South Africa through infrastructure security -especially of transport and particularly for the land-bolted nations in the region. In addition, the SADC adopted a Program of Action identifying and allocating a particular improvement or development projects to be sought after and led by specific countries. For instance, Mozambique coordinates transport, while Angola coordinate energy and Swaziland was given the responsibility for human capital development. Lamentably, this has centred party states' consideration around the coordination of national development rather than on a regional economic scheme.

The SADCC being transformed into the SADC through the 1992 Windhoek Treaty was obviously much more focused on economic issues than the former which was basically political security considerations. Debatably, what led to the transformation of the new institution of SADC into a Regional Economic Cooperation Economic was the increase in globalisation and liberalisation of trade apart from the increased in the proliferation of Regional Economic Cooperation and the rise of global value chains which played a key role in the transformation of the new institution of SADC, hence, its continuum moves up from regional cooperation to regional integration. Shortly after South Africa joined the SADC, South Africa was charged with the responsibility for coordination of the Finance, Investment and Health sectors. This is because South Africa has the most sophisticated financial and capital markets in the region and on the continent in general. At the end of the 1990s, the country led the development of the Protocol on Finance and Investment (FIP) and has additionally been giving key meeting and advice on the development of the Model SADC BIT - despite the centralisation of all functions, duties inside the SADC Secretariat in Gaborone.

South Africa is committed to the Regional Indicative Strategic Development Plan (RISDP) which is the SADC Blueprint for regional integration and improvement. This has been under survey since 2011 with this process being finalised earlier in 2013 (SADC, 2016). The SADC currently introduced the SIRESS (SADC Integrated 
Regional Electronic Settlement System) which processes high-value transactions, furthermore the region will soon also be able to accommodate low values; for example, EFTs (Electronic funds transfer -EFT). This payment system consists of an arrangement of instruments, saving money systems and interbank finance exchange components that guarantee the circulation of money regionally in the SADC and worldwide. Again, South Africa's skilled and experienced central bank authorities and the large commercial banks have assumed a noteworthy part in electrifying backing for this critical activity in the region. Absolutely, it certainly underlines South Africa's undeniable influence in the sub-region. South Africa is the financial hegemon in the locale - perhaps a reluctant hegemon. As the only African G20 member and the only BRICS member, it is an influential actor in both regional and international geo-legislative issues. It is by a long shot the locale's most industrialised member.

The consideration gets on the worldwide front helps to intensify the locale's issues, challenges and potential. Moreover, there is South Africa's perceived obligation towards African countries, counting Tanzania, Zambia, Mozambique, Zimbabwe, Guinea and even the littler land lock kingdoms of Lesotho and Swaziland for providing support to the anti-apartheid movement and a refuge to anti-apartheid activists. The principal equitable organisations of Nelson Mandela and Thabo Mbeki (between 1994 and 2008) in essence defined South Africa's character as a new democracy. While President Mandela underscored the advancement of human rights in Africa and South Africa's part in this, President Mbeki focused on the Pan-Africanist vision of the African renaissance (SAnews, 2016).

Since 1994, South Africa has organised the SADC offering to it the spirit and embodiment of the RISDP (Regional Indicative Strategic Development Plan). SACU provides the best example of the difficulty of South Africa's hegemonic position due to the contrast between its history of regional destabilisation and its repositioning post-apartheid. Nevertheless, the customs union was created in 1910 to make customs administration in the British territories and protectorates in Southern Africa less demanding to oversee - in this way a comfort for the colonial administration of the time, rather than a tool for economic development. Common customs policy within the region was dictated from Pretoria and the free internal trade encouraged the predominance of South African industry within the union. The apartheid government's importsubstituting protectionism was designed to stimulate industrialisation in South Africa - however, this was to the detriment of the other nation's modern development.

As a result, compensatory payments were made to Botswana, Lesotho, Namibia, and Swaziland (BLNS) as an incentive for the exchange redirecting impacts of South Africa's protectionist tariff structure. There was a political imperative to securing the BLNS' participation in SACU on account of South Africa's seclusion amid politically-sanctioned apartheid government. This brought about over-pay in the updated SACU revenue sharing agreement of 1969. A post-politically-sanctioned racial segregation South Africa (post-apartheid) renegotiated SACU's income sharing understanding in 2002 by which time the BLNS were heavily dependent on the customs revenue to fund their fiscal operations; the 2002 agreement being much more democratic and developmental. It included the redistribution of a large portion of South Africa' customs revenue to the smaller states (SADC, 2016).

With the strain on South Africa's monetary spending plan after the worldwide money related emergency and the developing levels of South Africa's public debt, there have been calls from many quarters within South Africa to recover a great part of the traditions income which is right now conveyed to BLNS. Be that as it may, the smaller SACU members are adamant that this redistribution is necessary to compensate them for the special access South African companies have had to their business sectors especially during South Africa's colonial and apartheid eras. Contrariwise, South Africa had argued that SACU's income pool should be moved towards financing modern advancement, and also cross-cutting infrastructural needs, rather than funding national fiscal budgets. However, as long as Swaziland and, Lesotho, for instance, get $60 \%$ of their GDP through SACU incomes and no differentiation in their tax base, SACU will never be a meaningful regional development organisation with SADC (SADC, 2016).

The degree of regional economic integration in SADC is frequently thought to be truly falling behind other RECs in Africa. While the SADC has committed to following a linear economic integration plan, moving from an unhindered commerce area to a customs union, and in the long run finishing in a common market with a single currency, it has consistently missed its convergence targets and there has been a lack of serious 
engagement in pursuing the RISDP integration plan. However, the linear integration path is based on the EU integration model and the wholesale application in an African context is questionable at best. Debatably, SADC's intra-regional trade has not performed significantly well as expected since 2008 as a free trade area. Alternatively, South Africa has developed its own model of regional economic integration which it trusts fits the African setting better. This is called a functional regional integration; a model takes a lateral approach and focuses on consolidating the free trade territory in SADC by tending to non-tax barriers to help market integration and creating regional trade infrastructure. This is a positive development since the lack of success of the organised commerce territory in opening regional exchange or trade is demonstrative that non-levy hindrances are more culpable in stifling intra-SADC trade than tariff barriers. The Non-tariff barriers (NTBs) can range from costly and burdensome customs proceduresto regulatory red-tape, to bribery and corruption among customs and immigration officials, to health and safety standards which are sometimes applied to protect local industry.

The Southern Africa's colonial history put its transport and trade infrastructure largely on getting primary commodities from the point of extraction to the coast for exportation to Europe or North America, rather than facilitating trade among Southern African countries (Austin, 2010). Unfortunately, despite the sense in this argument, it has not received the needed political buy-in from SADC states, and on-the-ground implementation of its associated policies has been slow. This is partly due to a mistrust of regional economic integration among stake holders and policy-makers in the SADC. It therefore means that convincing member states to sign onto the free trade area would be a herculean task for the SADC. According to the Institute for Global Dialogue (2008) and up to early 2017, Angola, DRC and Seychelles are still not signatories, as they have asked for more time. When it became evident that the free trade area did little to boost regional trade and increase the rate of economic development, member states began reneging on the provisions of the agreement and erecting other non-tariff barriers to trade. Despite the SADC (and two other RECs) having set up an online monitoring mechanism which allows the private sector to register the Non-Tariff Barriers (NTBs) they experience, SADC's decision to reject litigious dispute settlement means that there is no recourse to be taken against an offending country unwilling to cooperate. This is indicative of a broader issue within SADC. While SADC heads of state often pay lip service to the importance of deepening regional integration, there is an unwillingness to sacrifice national sovereignty to the regional body. SADC has a central secretariat without the necessary institutional bolstering, and many of the regional bodies such as the SADC Tribunal, are either powerless to enforce regional policy or have completely failed. As such, it seems as though the regional economic integration agenda is not going to be driven by the public sector whether at national or regional level. Rather, attention has shifted to the role of the private sector in driving regional integration in the SADC.

The business sector has shown a keen interest in being involved in regional policy-making and aiding in eliminating NTBs. With the private sector's access to expertise, experience and resources, a greater level of public-private engagement is called for. Unfortunately, in the SADC this engagement is low partly because organised business in the SADC is weak (Lesley, n.d). Whereas other RECs in Africa have strong regional business apex bodies that can distill private sector representation into a single platform, organised business in the SADC is fragmented and partial to being captured by sectorial interest. It is also because many Southern African states see the private segment as a source of income gathering instead of as important improvement partnership. The various licenses and administrative charges connected to cross-border transporters speak to charges on working together instead of financial arrangement tools intended for attractive results. Tripartite Free Trade Area (TFTA), negotiation around Africa's own mega-regional trade agreement started in 2008. Just as the WEF (World Economic Forum), question whether mega-regionals are global economic game-changers or, in fact, costly distractions, the Tripartite Free Trade Area will bring together 26 Member States in one market of nearly 600 million people. The TFTA makes up 57\% of the population of the African Union (AU) and just over 58\% in terms of GDP - approximately \$ 624 billion. The launch of a regional free trade area has remained something of a moving target since 2011 when the tripartite agreement was adopted. The Tripartite FTA should have been officially launched in June 2014. However, this deadline was missed owing to the closure of its erstwhile secretariat, Trademark Southern Africa perhaps for [economic] reason on the part of South Africa; the launch later took place in December, 2014 (SADC, 2016).

South African policy makers see the T-FTA against a type of 'developmental regionalism' which focuses on poverty reduction through industrialisation and economic growth. Nonetheless, Trans-regional transport 
infrastructure and the coordination of economic policy are essential. The T-FTA is based on three pillars: Market integration, Infrastructure development and, Industrialisation. These pillars are relied upon to address the key difficulties which oblige the intensity of African businesses and consequently limit Africa's integration within the global economy. The T-FTA priorities also find resonance in South Africa's own policy documents such as The New Growth Path, the National Development Plan (NDP) and the IPAP 1\&2 (Industrial Policy Action Plans), -The Medium-term Strategic Framework (MTSF) 2014-2019 of South Africa has therefore been seen to position the Industrial Policy Action Plan (IPAP) as one of the key mainstays of radical change in South Africa, in view of comprehensive development in the gainful areas of the economy (DTI, 2016). The various attempts made to encourage economic integration in Africa have led to countries belonging to multiple regional economic communities implying competing priorities and conflicting requirements - characterised by contested implementation schedules and commitments of the different trade regimes, which fundamentally undermine their effectiveness. To enable greater competition with other strong economies in the regions such as Kenya and Egypt, South Africa's role in the region has transformed profoundly where various groups - public, private and civil society have sought new forms of collaboration and cooperation, for Instance, poverty reduction, economic development, peace and security and governance support. Moreover, South Africa's dominance in the Sub-Saharan African region also calls into question whether regional integration will show any significant progress without the commitment from South Africa and we all wait to see exactly what level of commitment this actually is (SADC, 2016).

Promoting South African National Development: The consistency and relevance of REI for South Africa or Southern Africa in the future is another matter for discussion. The future of the Southern Africa sub-region would depend on choices made in South Africa. A leading South African scholar stated that 'irrespective of the political introduction of a future South African government, all aspects of regional interaction are bound to undergo far-reaching change' (Leistner, 1992b:10). Debatably, the issue has gotten to be not whether the region ought to incorporate monetarily but rather the coordination - who, how and when. Robert (1994) while expressing a fundamentally alternate point of view argued that various powers in South African approach on the terms, standards, and approaches to govern a programme of closer regional economic cooperation and integration after apartheid for the perpetuation of self-interest. The South African future policy on this issue can thus be expected to depend on a considerable extent on the balance of forces established in the negotiation process.

The South Africa's National Economy Development Policy: Apparently, it has been argued that the approach to national economic development by various powers in South African has been on the terms, standards, and approaches to govern a programme of closer regional economic cooperation and integration after apartheid for the perpetuation of self-interest (Robert, 1994). The South African future policy on this issue can thus be expected to depend on a considerable extent on the balance of forces established in the negotiation process. Currently the only African member state in the Group of 20 (G-20) according to Jonas (2012), is South Africa, and in this manner conveys the weight of its own national advantages as well as of being a voice for the concerns of African and low wage nations (least developed nations). While South Africa has no official command to represent any other member but itself in the G-20, there is verifiable weight to guarantee that those nations and foundations who take part in the G-20 forms at any rate see a portion of the effects that their choices may have on African non-state members. This has been reflected in the dynamic part South Africa has played in the G-20 on improvement, International Monetary Fund (IMF) change and all the more as of late tax collection. South Africa works intimately with other developing nation entities from the group to guarantee that there is an adjusted plan and a scope of alternate points of view set forward on issues of specific significance to the worldwide south.

\section{South Africa Key Economy Performance since 1994}

Economic Performance: It is true that the South African economy has experienced a substantial change in the recent period since the appearance of democracy. The nation has recorded a normal rate of economic development and growth of 3.3\% annually in genuine terms over the period 1994 to 2012 . This growth rate was a momentous change from the $1.4 \%$ typical yearly advancement enlisted in the midst of the periods of 1980 to 1993. In any case, the pace of development missed the mark regarding the $3.6 \%$ average as recorded by the world economy. South Africa's total national output (GDP) by 2012 was $77 \%$ or greater compered to 
1994 and an increment 90\% compared with the global economy (IDC, 2013). On per capital premise, the country's genuine GDP was 31\% higher before the end of the period. Advancement has, in light of current circumstances, been very unstable and firmly connected to the global monetary performance. The period depicted by the East Asian economic recession around 1998 mirrored a more amazing downturn for South Africa's economy as it was at the same time adjusting to its reintegration into the world economy. This event began a disparity between the whole deal GDP execution cases of the household and overall economies (IDC, 2013).

Manufacturing sector of the economy: The manufacturing sector's relative commitment to the general South Africa GDP and business declined in the course of the past two decades as South Africa formally entered a technical recession. As indicated by Sunita Menon on Business Day (2017), the GDP (Gross Domestic Product) shrunk by $0.7 \%$ quarter on quarter in the 1 st quarter of 2017 - a stun as the consensus among financial specialists was a bounce back to $0.9 \%$ development or growth. The rand debilitated more than $1 \%$ against real exchanging monetary forms, tumbling to R12.84 against the dollar, R14.45 against the euro and R16.59 against the pound at 11.41am. A technical recession depends on two sequential quarters of negative growth. Gross domestic product in the final quarter of 2016 shrunk by $0.3 \%$. The biggest negative supporters of development were the exchange, providing food and housing industry which dropped by 5.9\% and diminished 0.8 of a rate point from GDP development (around R16bn to R148bn) and the assembling part shrunk by 3.7\%, down 0.5 of rate point from GDP development (around R4bn to R129bn). Mining was around R14bn to R129bn while government consumption was around R2bn to R170bn (Business Day, 2017).

Gross domestic product is up 1\% contrasted with a similar period a year ago. Joe de Beer, Statistics SA appointee executive general of monetary insights, said on Tuesday: "We have officially entered a recession. The last time we entered a recession was 2008-9 when we had three consecutive quarters of negative growth." He added: "There's a clear link between the fall in household consumption expenditure and the decline in trade. "Family utilization consumption was down $2.3 \%$ quarter on quarter. Stanlib boss business analyst Kevin Lings said it was particularly worried that since the global financial market crisis in 2009, the rate of monetary development in South Africa had not figured out how to pick up force and had not been sufficiently vigorous to prompt boundless occupation creation in the private division. This is in spite of government obligation practically multiplying since 2009 . There needs to now be a genuine hazard that South African duty income gathering fails to meet expectations considerably all the more, putting the monetary specialists under critical pressure,' he said (Business Day, 2017).

In spite of the fact that it attested the overarching position in the economy in 1994, when it represented up to $21 \%$ of GDP at current costs, the part accordingly turned into the fourth greatest by 2012 (12.4\% of GDP). Be that as it may, a contracting offer does not imply a decrease in yield in certifiable terms producing GDP extended by $61 \%$ from 1994 to 2012 . The sector additionally turned out to be progressively exports-oriented with its share of aggregate stock exports remaining considerably higher in 2012 (IDC, 2013). The manufacturing industries, broadened generally, were dominated by a couple of substantial sub-sectors, particularly chemicals, metals and apparatus, and in addition food processing. Nevertheless, both the chemicals and food industries amplified their different shares of manufacturing value since 1994 while that of machinery and metals remained fundamentally unaltered. Furthermore, the textiles and clothing sector contracted substantially, but many other manufacturing sub-sectors are mainly domestic market oriented while others are profoundly dependent on export markets. Intensity is basic to their prosperity as rivalry prevailed in all cases. Performance was influenced by various elements after some time, including both domestic and external demand state of affairs, currency developments, input expenses and pricing practices for example; import equality valuing or pricing, mechanical redesigning, policy support, infrastructure and coordination, administrative aspects and tax insurance or tariffs, and issues with competition/concentration, among others. They were profoundly advocated and supported for a long period of time by industrial policy initiatives while the transport equipment sector reliably by-passed the manufacturing industries (IDC, 2013).

According to report by the Industrial Development Corporation (2013), the machinery and metals industries posted a reasonably solid execution from 2002 to 2008. This was unequivocally reinforced by development and different types of fixed venture activity and its fair introduction. Be that as it may, the sectors' contribution was negative in 2009 when a $20 \%$ decline was recorded. Since the start of the economic 
recession, the non-metallic mineral items industries saw a negative average development which was influenced by weaker development. In addition to that, in the sub-sectorial level, the biggest picks up at the end of the recession in actual value added over the period 1994 to 2012, among the greatest industries of manufacturing were recorded with the accompanying: petroleum items; engine vehicles, parts and frill; "diverse chemicals"; equipment and equipment or machinery; essential chemicals and electrical hardware. The food handling enterprises contributed $11.2 \%$ to the manufacturing sector's GDP at an advanced rate over this period which was indistinguishable to the economy's 77.1\% development (IDC, 2013).

Services Delivery sector of the economy: Government and the exercises its administrative cum political power are the consequence of political progression. The administration is the support of lawfulness, the resistance of society against outer adversaries and the headway of what is thought to be the welfare of the gathering, group, and society or state itself. The government, is in this way, in charge of making laws and guaranteeing that there are establishments to actualize its laws, and giving the administrations and items that these laws are implemented. It is the implementation of laws and the real planning of governments that constitute administration. The government's projects ought to, in this manner, contribute towards an enhanced personal fulfilment for all.

Tourism: Tourism is another key area where revenues are generated by most advanced countries. Currently, tourism is viewed as an engine or instrument of development and has become one of the biggest enterprises universally. One of the benefits of tourism as an export recipient is that it is less unstable than the product sector. Tourism has been reserved as a development industry in South Africa as the business is in a perfect world suited to enhancing the nation's numerous normal, social and different assets. As indicated by the World Travel and Tourism Council (2017) report, tourism constitutes roughly 7\% of GDP and work in South Africa. Somewhere in the range of $74 \%$ of all guests in 2006 were from Africa and around $26 \%$ from abroad. Around 7.9 million of the 8.5 million remote explorers (92\%) went to the nation for an occasion and roughly $196951(2.3 \%)$ for business in 2006.

It was likewise reported by the World Tourism Organization (WTO), sub-Saharan Africa pulled in 2.9\% of the world's travellers in 2005. Of this rate, South Africa has around $20.5 \%$ of a piece of the pie. South Africa's global tourism earnings added up to \$7.3-billion in 2005. Its share of aggregate African traveller landings and tourism receipts was more than $34 \%$ in 2005 . Nevertheless, in a more recent report according to the WTTC 2016 Economic Impact report, Iceland's Travel and Tourism add up to commitment was expected to ascend by $1.7 \%$ from 2015 to 2016 . In spite of the fact that information demonstrates that business development has hindered, this is just a transitory marvel. The standpoint for the fate of the industry or sector was certain, particularly bearing in mind the impact of the 2010 FIFA World Cup held in South Africa. The development to the occasion, and the introduction that South Africa brought previously, then after the fact the occasion, had undoubtedly brought about forceful development in foreign tourism. This became a demonstrated reality in each nation where the occasion has been held over the past years. It was anticipated that in 2010 the South African tourism industry had utilise more than 1.2 million individuals whichever directly or in the public sector either directly or indirect way (MCSA, 2016).

Local business in South Africa: Insights South Africa delivers a regular assessment of the retail trade business with local industries covering different retail exchange activities. The overview for the most part covers retailers in specific items of trade including food, beverages, beauty care products and toiletries, pharmaceutical, general merchants, tobacco, and therapeutic merchandise, materials, garments, footwear, cowhide products, family unit furniture, machines and gear, equipment, paint and glass, and also other distinctive shippers in irregular items. Since the year 2000 it was accounted for that retail trade or exchange bargains was at a steady cost, in the year 2006, it showed increase of 9.7\% from 2005 which recorded $7.2 \%$. According to Statistics on South Africa, this is the greatest addition, together with the 2004 augmentation, and this was additionally $9.7 \%$, for any year since 2000 . According to a survey by to Statistics SA, general traders, diverse retailers and retailers in materials, attire, footwear and cowhide items were the genuine patrons to the extension in retail trade bargains. Bona fide retail arrangements' advancement decreased in the last quarter from the second last quarter of 2006 from 10.7\% to $9.1 \%$ year-on-year. Among the huge retailing groups are Edcon, Massmart, Pick 'n Pay, Shoprite Checkers, Mr Price Group, Foschini Group, JD Group and Ellerines Holdings (MCSA, 2016). 


\section{Conclusion}

As earlier said, African regional cooperation has nevertheless been revitalised in some ways as a result of the two major events or developments which started in the beginning of the 1990s which include the obliteration of the apartheid regime in South Africa and eventual stabilisation of political and economic relationships in the Southern Africa sub-region. This, debatably, helped to deepen the already existing regional integration in the Southern Africa States. Since the end of the Cold War, and with the rise of capable exchanging coalitions, there has been a renewed interest in South Africa regarding the need to create strong REI mechanisms to promote economic growth for the region and by implication foster South Africa's National Development trajectory. After becoming democratic in 1994 and subsequent acceptance into the SADC, the South African economy has achieved both social and economic development within the last two. There are few factors considered to be responsible for the economic development of South Africa. The economy became stabilised in the mid-2000s as the country experienced an improved social development. Nevertheless, from a policy perspective, South Africa has fallen short significantly particularly in relation to economic reforms. Economic reform has been weakened as a result of poor policy development which lacks the right vision for the economy.

Broadly speaking, South Africa in the past few years has experienced a continuous successive growth its economy, thus regarded as the long-lasting and sustained economic development in its recent history. The continued growth and sustainability is a result of prudent fiscal and monetary management with her increased participation of the corporate sector in overall economic activity. Regardless of the economic challenges and policies implementation faced by the South Africa since 1994, South Africa has played a very vital role in the Southern Africa sub-regional integration since her acceptance into the SADC. Her role in the SADC has transformed profoundly whereby different groups both public, private and civil society sectors sought new forms of partnership and cooperation in the area of poverty reduction, peace and security, governance support, and economic development. Having carefully examined the various key economic performance of the economy of South Africa since 1994, it is, therefore, safe to conclude, that, regardless of its political and economic management of SADC through her various international companies all around the region, South African FDI is mainly contributed by her heavy investment and market penetration in Southern Africa region, nevertheless South Africa also depends heavily on her foreign investment for its continued growth. The injection of investment funds (FDIs) from abroad is essential to guarantee the best possible operation of the nation's unlimited assets which has contributed to continued growth of the economy. These investments returns are the functions and basis of South Africa's national development today.

\section{Reference}

Bolaños, A. B. (2016). A step further in the theory of regional integration: A look at the Unasur's integration strategy. Working paper GATE2016-17.

Business Day.(2017).SA officially in recession after shock GDP number 06 JUNE 2017 - 11:35 SUNITA MENON.https://www.businesslive.co.za/bd/economy/2017-06-06-sa-officially-enters-recession/ Accessed September 52017

Chingono, M. \& Nakana, S. (2008). The challenges of regional integration in Southern Africa. African Journal of Political Science and International Relations, 10(3), 396-408.

Dey, I. (2005). Qualitative Data Analysis. London: Routledge, Taylor and Francis Group.

DTI. (2016). Zimbabwe to Address Trade Restrictions. Media Statement, Department of Trade and Industry.http://www.thedti.gov.za/editmedia.jsp?id=3816 Accessed December 82016.

ECLAC. (2009). Physical Infrastructure and Regional Integration, ECLAC Bulletin: Facilitation of trade and transport in Latin American and the Caribbean, 12(280), 1-4.

Etzioni, A. (1965). Political Unification. New York; Holt Rinewartaud Winstone.

Fall, F., Vachon, B. \& Winckler, C. (2014). Regional Integration: Comparison between SADC and ECOWAS. In D. Seck (Ed.) Regional Economic Integration in West Africa: Advances in African Economic, Social and Political Development. Switzerland: Springer.

Hans, J. M. (1978). Politics among Nations: The Struggle for Power and Peace. New York: Alfred A. Knopf.

IDC. (2013). South African economy: An overview of key trends since 1994. December 2013. 
Institute for Global Dialogue. (2008). Liberalising trade in Southern Africa. Implementation challenges for the 2008 SADC FTA and beyond. Proceedings of the Fifth Southern African Forum on Trade (SAFT) held in Pretoria, South Africa, on 6-7 August 2008.

Jephias, M. \& Muyengwa, M. (2014). The SADC regional bloc: What challenges and prospects for regional integration? Law, Democracy and Development, 18 Cape Town

Jonas, M. (2012). When is Foreign Direct Investment Beneficial to a Country and When Is It Not? The Case of South Africa. SAIIA Policy Briefing No 44, February 2012.

Jonathan. (2004). African Regional Integration: A Spotter's Guide. http://headheeb.blogmosis.com/archives/019886.html Accessed 3 December 2016.

Leistner, E. (1992). Designing the Framework for a Southern African Development Community. Africa Insight, 22(1).

Lesley, W. (n.d). South Africa and the regional economic integration agenda: Priorities and Perspectives. Speaking Notes

Lindberg, L. N. (1963). The Political Dynamics of European Economic Integration. Stanford; Stanford University Press.

Lindberg, L. N. (1970). Political Integration as a Multidimensional Phenomenon Requiring Multivariate Measurement. International Organization, 24(4), 649-731.

Muneer, S., Jahanzeb, A. \& Suwandi. (2016). Income diversification and performance: a comparison of commercial and Islamic banks of Pakistan. Abasyn Journal of Social Sciences, Special Issue, 471-485

Mutisi, M. (2016). SADC Interventions in the Democratic Republic of the Congo. African Centre for Constructive Resolution of Disputes

Omoro, M. F. A. (2008). Organisational Effectiveness of Regional Integration Institutions: A Case Study of the East African Community. Master Dissertation submitted to the Department of Public Administration, University of South Africa.

PVW/SouthAfrica.http://www.pwc.co.za/en/publications/right-plan-for-private-sector participation. html. Accessed September 212016.

Roberts, D. (1994). Approaches to Regional Integration in the Southern African Context. Africa Insight, 24(1), 11-17

SADC. (2016). The Free Trade Area. Southern Africa Development Community.http://www.sadc.int/aboutsadc/integration-milestones/free-trade-area/ Accessed September 132016.

SAHO. (2015). The African Union and Regional Economic Integration. (South African History Online)

SAnews. (2016). SA elected as the chair of SADC. http://www.sanews.gov.za/south-africa/sa-elected-chairsadc Accessed February 202017.

Schmitter, P. C. (1970). A Revised Theory of Regional Integration. International Organization, 24(4), 836-868.

The Telegraph. (2017). Zimbabwe army chief warns Mugabe's party that military may intervene after sackingshttp://www.telegraph.co.uk/news/2017/11/13/zimbabwe-army-chief-warns-mugabesparty-military-may-intervene/ Accessed 14 November 2017

World Trade Organization. (2016). World Trade Organization. Principals of the Trading System.

World Travel \& Tourism Council. (2017). Travel \& Tourism Economic Impact 2017 South Africa. (WTTC) 